\title{
The Relationship between Ownership Structure and Risk Management: Evidence from Iran
}

\author{
Sheyda Lotfi \\ Department of Accounting, Kurdistan Science and Research Branch, Islamic Azad University, \\ Sanandaj, Iran \\ Dr. Ataollah Mohammadi \\ Department of Accounting, Sanandaj Branch, Islamic Azad University, Sanandaj, Iran \\ DOI: $\quad 10.6007 /$ IJARBSS/v4-i2/594 URL: http://dx.doi.org/10.6007/IJARBSS/v4-i2/594
}

\begin{abstract}
This research aims to study the relationship between the Ownership Structure and Risk Management in time period between 2007 to 2013 based on a sample including 642 Year_Firm among campanies listed in Tehran Stock Exchange. In following for each of the variables related to the Ownership Structure such as Institutional Ownership, Management ownership, Family Ownership, and Ownership Concentration, a hypothesis is formulated and its impact upon the Risk Management is investigated. The simple liner regression and multiple regression were used to examine the hypothesis. The results indicate that there is a significant positive correlation between the Management Ownership and Risk Management; Also there is a significant negative correlation between the Ownership Concentration and Risk Management. But, there is no significant correlation between the Institutional Ownership and the Family Ownership with Risk Management.
\end{abstract}

Keywords: Risk Management, Ownership Structure, Tehran Stock Exchange.

\section{Introduction}

One of the important issues in recent decades, researchers have noted, is contrary to the interests of shareholders and Management. According to related researches with corporate governance, ownership structure is one of the ways to solve this problem. According to agency theory, ownership structure as part of corporate governance, efforts to minimize the costs associated with the separation of ownership and control of the company. Agency costs in firms with high managerial ownership share, to align the goals of managers and shareholders are lower, And large block shareholders in companies that are able to monitor managerial activities, are lower. The ownership structure of governance and policy through efficient, has an impact on firm performance, Including Risk Management. One of the key issues in corporate governance is aware of the ownership structure, using the strategies to be developed for better performance company. This study is based on the relationship between ownership structure variables and interactive effects of these variables to assess Risk Management. 


\section{Literature Review and Background}

Esta[2011] found out the significant impact of Institutional Ownership, Corporate Ownership in $\mathrm{TSE}^{1}$, and Management Ownership on Earnings Management; Also kumera and Gue[2012]from SriLanka indicated the effect of Management Ownership on the performance of companies. Some researches showed that there is a significant negative relationship between Institutional Ownership and firm's Efficiency, such as [Aghaii and Chalaki,2010]; But some of them showed the positive effect of Institutional Ownership on firm's Efficiency, like[Setayesh et al,2010; Ghanbari,2007; Vadiee and Gholampoor,2011; Mehrani et al,2011; Hasas.Y et al,2008].

Mohammadi and Lotfi[2013] found out the significant assocation between Board of Director Composition and Risk Management in TSE. Also Prasetyo[2011], showed that there was a significant relationship between Corporate Governance and Systematic Risk in Indoneesia's firms. Lio and Zhu[2009] showed that the Ownership Structure impacted on Systematic Risk.

Aldamen et al[2010]in Australia, and Guangming et al[2011]in China showed that improving Corporate Governance would redused Risk.

Mahavarpoor[2007] in her study indicated that the significant relationshipbetween Ownership Concentration and EPS;Though the findings of Aghaii and Chalaki[2010]are contrast with hers.

\section{Variables}

Variables to test the hypotheses of this study, three groups of independent variables, dependent and control are divided.

\subsection{Institutional ownership}

In this study according to the definition of Pourheydari and Hemmati [2004] Total equity investment companies, foundations, institutions and government agencies, because of the long-term horizons have been considered as institutional shareholders.

\subsection{Property Management}

According to agency theory, when managers are also the owners of a company in general there is a convergence of interests between managers and owners [McNieght and Weir, 2008]. So the percentage ownership of directors as a corporate governance mechanism can be effective in Rsk Management company.

\subsection{Family ownership}

Evidence in the literature of agency theory suggests that an increase in the ownership and Management of family shareholders to reduce agency conflicts [Elghol et al, 2007].

\subsection{Ownership concentration}

Ownership concentration is the distribution of shares between shareholders of different companies. As the number of shareholders is less, ownership will be more concentrated [Mohammadi et al, 2009]

${ }^{1}$ In this study, TSE means Tehran stock Exchange. 


\section{Dependent variable}

In this research, Risk Management of listed companies in Tehran Stock Exchange is considered as the dependent variable, which is defined as follows:

\subsection{Risk Management}

It is the process through which an organization or an investor react with an optimal manner against a variety of Risks. Accordingly, the risk manager should identify the types of risks, Then they measure and assess its effects on the financial situation of the Organization, and the proper means to be employed to reduce or eliminate Risk [Ibrahami, Ghanbari, 2006]. In this study, Sharpe single index model, which beta is introduced as a measure of systematic Risk that will be used for the estimation of Risk Management.

\section{Control variables used in this study include:}

\subsection{Firm size}

In the present study, as French J et al [2012] The natural log of the firm's stock market value is used as a measure of firm size. In order to control the size of the impact on wealth creation through economies of scale, bargaining power and the exclusive power to do so.

\subsection{Debt structure or financial leverage}

That the ratio of total debt to book value of total assets is measured. This aims at controlling the impact of debt on corporate performance is covered.

\section{Research Hypotheses}

4.1. There is a significant correlation between the Institutional Ownership and Risk Management of the listed companies in TSE.

4.2. There is a significant correlation between the Management Ownership and Risk Management of the listed companies in TSE.

4.3. There is a significant correlation between the Family Ownership and Risk Management of the listed companies in TSE.

4.4. There is a significant correlation between the Ownership Concentration and Risk Management of listed companies in TSE.

\section{The Research methodology}

The method used in this study is Descriptive and Correlation. For collecting our data we used a post_hoc approach and collected them from Tehran Stock Exchange's websites. Also for the data analysis the software SPSS16, Ewius7 and Excel were used.

\section{The Research Population and The Sample}

The population of the research includes all companies listed in Tehran Stock Exchange, from 2007 to 2012. The method of Systematic Removal, is used as explained in the following:

- In order to increase the comparability, their fiscal periods end in Last month of Solar year; And During the years 2007 to 2012, there must be no change in financial year and the operations not skipped.

- Financial statements, accompanying notes and annual reports of the mentioned period must be completely present in the Exchange website 
- The Book value of equity interests must not be negative during the period under discussion. Also, Companies must be profitable; And the intended company must be consistently active during the study period and its shares be traded.

- The selected company must not be a part of investment companies, financial intermediation, banks, insurance, holding, leasing and etc, because the methods of financial reporting and corporate governance in these companies are different .

With regards to the above conditions, 642 year-firm were selected as the sample.

\section{Methods and Tools of Data Analysis}

In this study, regarding the type of data and methods of analysis, the method of "combined data" is used. The combined data means a set of data consisting of a large number of descriptive variables $(N)$ which during a specified time period $(T)$ are examined. As such, the observations would be $\mathrm{N} \times \mathrm{T}$ which can be estimated using different models. Therefore, in this study, the combined data analysis is used. The models of this research which related to our hyphothes are presented as follows:

1. $R M_{\text {it }} \alpha+\beta_{1}$ INSTOWN $_{\text {it }}+\beta_{2}$ FSZE $_{\text {it }}+\beta_{3}$ LEV $_{\text {it }}+\varepsilon_{\text {it }}$

2. $R M_{i t}=\alpha+\beta_{1} M_{O W N}+\beta_{2} F_{\text {FZE }}+\beta_{3} L_{E V}$ it $+\varepsilon_{\text {it }}$

3. $R M_{i t}=\alpha+\beta_{1} F_{O W N}+\beta_{2} F_{\text {FZE }}+\beta_{3}$ LEV $_{\text {it }}+\varepsilon_{\text {it }}$

4. $R M_{i t}=\alpha+\beta_{1} O W N C O N_{i t}+\beta_{2} F_{S Z E} i t+\beta_{3} L E V_{i t}+\varepsilon_{i t}$

Where

$\mathbf{R} \mathbf{M}_{\mathrm{it}}=$ Risk Management in Year $\mathrm{t}$ for Firm i

Note:In this model, systematic Risk $(\beta)$, is used as an indicator to measure Risk Management.

$\beta_{i}=\frac{\operatorname{cov}\left(r_{i}, r_{m}\right)}{\sigma^{2}\left(r_{m}\right)}$

INSTOWN $_{\text {it }}=$ Institutional Ownership in Year t for Firm i

$\mathbf{M O W N}_{\mathbf{i t}}=$ Management Ownership in Year t for Firm i

FOWN $_{\text {it }}=$ Family Ownership in Year $t$ for Firm i

OWNCON $_{\text {it }}=$ Ownership Concentration in Year t for Firm i

FSZE $_{\text {it }}=$ Firm Size in Year $\mathrm{t}$ for Firm i

LEV $_{\text {it }}=$ Financial Leverage in Year $t$ for Firm $\mathrm{i}$

$\boldsymbol{\varepsilon}_{\mathrm{it}}=$ Error in regression model in year $\mathrm{t}$ for Firm $\mathrm{i}$

\section{Analysis Method}

Table 1. Statistical Tests Needed for Regression Analysis

Type of Test The Statistic Used

Significance of the Total Regression Equation Statistic F, ANOVA test

Significance of Singular Coefficients Statistic $\mathbf{t}$

Self-Correlation

Durbin Watson 


\section{Results of Multivariate Regression}

\subsection{The first regression Test:}

Based on the results in Table 2, it can be seen that there is a Negative correlation between the Institutional Ownership and the Risk Management meaning that by increasing of Institutional Ownership, the Risk Management decreases. Also, the regression equation regarding the statistic $\mathrm{F}=0.954$ at sig $=0.414$ indicates that the overall equation is not significant; However, both statistics Durbin Watson DW and Durbin h with values of 1.653 and 1.3327 confirm the lack of serial autocorrelation problem in the model.

Table2. Regression between Institutional Ownership and Risk Management with control variables

\begin{tabular}{|c|c|c|c|}
\hline \multicolumn{2}{|c|}{ Depended Variable: Risk Management } & \multicolumn{2}{|c|}{$Y=0.037$ INSTOWN-0.41LEV+0.034FSZE } \\
\hline Variables & Coefficients & $\begin{array}{l}\text { Statistic } \\
\mathrm{t}\end{array}$ & Probability Statistic $\mathrm{t}$ \\
\hline The Slope of Line(Fixed Amount) & 0.197 & 0.393 & 0.695 \\
\hline Institutional Ownership & 0.037 & 0.921 & 0.357 \\
\hline LEV & -0.41 & -1.021 & 0.308 \\
\hline FSZE & 0.034 & 0.840 & 0.401 \\
\hline$\left(R^{2}\right)$ Coefficient of Determination & \multicolumn{3}{|c|}{0.067} \\
\hline Adjusted Coefficient & \multicolumn{3}{|c|}{0.004} \\
\hline Statistic F & \multicolumn{3}{|c|}{0.954} \\
\hline F Probability Statistic & \multicolumn{3}{|c|}{0.414} \\
\hline Durbin Watson & \multicolumn{3}{|c|}{1.653} \\
\hline DW Statistic H & \multicolumn{3}{|c|}{1.3327} \\
\hline
\end{tabular}


Table 3. The Analysis of ANOVA

\begin{tabular}{|c|c|c|c|c|c|c|}
\hline \multicolumn{3}{|c|}{ Model } & \multirow{2}{*}{$\begin{array}{c}\begin{array}{c}\text { Total } \\
\text { Squares }\end{array} \\
2.290\end{array}$} & \multirow{2}{*}{$\begin{array}{c}\begin{array}{c}\text { Degree of } \\
\text { Freedom }\end{array} \\
3\end{array}$} & \multirow[t]{2}{*}{ F value } & \multirow{2}{*}{$\begin{array}{c}\text { F probability } \\
\text { (sig.) }\end{array}$} \\
\hline Dependent & \multirow{3}{*}{ Risk } & Regression & & & & \\
\hline $\begin{array}{l}\text { Variable: } \\
\text { Management }\end{array}$ & & Residual & 510.573 & 638 & 0.954 & 0.414 \\
\hline & & Total & 512.863 & 641 & & \\
\hline
\end{tabular}

\subsection{The second regression Test:}

According to the table 4, it can be seen that there is a direct positive correlation between the Management Ownership and Risk Management meaning that by increasing in the Management Ownership, Risk Management increases. This correlation according to the regression coefficient and statistic $\mathrm{t}=1.901$, sig $=0.058$ is statistically significant. Also, the regression equation regarding the statistic $\mathrm{F}=2.879$ at sig 0.032 indicates that the overall equation is significant. However, both statistics Durbin Watson DW and Durbin h with values of 1.661 and 1.34037 confirm the lack of serial autocorrelation problem in the model.

Table 4: Regression between Management Ownership and Risk Management with control variables

\begin{tabular}{lccc}
\hline Depended Variable: Risk Management & \multicolumn{2}{l}{ Y=0.075MOWN-0.037LEV+0.028FSZE } \\
\hline Variables & Coefficients & Statistic t & Probability Statistic t \\
The Slope of Line(Fixed Amount) & 0.476 & 0.960 & $\mathbf{0 . 0 3 7}$ \\
Management Ownership & 0.075 & 1.901 & $\mathbf{0 . 0 5 8}$ \\
LEV & -0.037 & -0.936 & $\mathbf{0 . 0 4 0}$ \\
FSZE & 0.028 & 0.698 & $\mathbf{0 . 0 2 6}$ \\
( R ${ }^{2}$ ) Coefficient of Determination & & $\mathbf{0 . 1 9 4}$ \\
Adjusted Coefficient & & $\mathbf{0 . 0 0 9}$ \\
Statistic F & & $\mathbf{2 . 8 7 9}$ \\
F Probability Statistic & \multicolumn{2}{c}{$\mathbf{0 . 0 3 2}$} \\
Durbin Watson & $\mathbf{1 . 6 6 1}$ \\
DW Statistic H & $\mathbf{1 . 3 4 0 3 7}$ \\
\hline
\end{tabular}


In Table 5, the results of the ANOVA test for the model above shows that in this model also, the null hypothesis is rejected and therefore, the counter-assumption has been proved by 95 percent confidence level.

Tabale5. The Analysis of ANOVA

\begin{tabular}{|c|c|c|c|c|c|c|}
\hline \multicolumn{3}{|c|}{ Model } & \multirow{2}{*}{$\begin{array}{c}\begin{array}{c}\text { Total } \\
\text { Squares }\end{array} \\
4.492\end{array}$} & \multirow{2}{*}{$\begin{array}{c}\text { Degree of } \\
\text { Freedom }\end{array}$} & \multirow[t]{2}{*}{ F value } & \multirow{2}{*}{$\begin{array}{c}\text { F probability } \\
\text { (sig.) }\end{array}$} \\
\hline Dependent & \multirow{3}{*}{ Risk } & Regression & & & & \\
\hline $\begin{array}{l}\text { Variable: } \\
\text { Management }\end{array}$ & & Residual & 508.372 & 638 & \multirow[t]{2}{*}{2.789} & \multirow[t]{2}{*}{0.032} \\
\hline & & Total & 512.863 & 641 & & \\
\hline
\end{tabular}

\subsection{The Third Regression Test:}

The results in Table 6 , we can see that the correlation between Family Ownership board and Risk Management is not statistically significant regarding the regression coefficient and statistic value of $t=1.202$, sig=0.230. Also, the regression equation regarding the statistic $F=1.153$ at sig $=0.327$ indicates that the overall equation is not significant. However, both statistics Dorbin Watson DW and Durbin h with values of 1.661 and 1.336335 confirm the lack of serial autocorrelation problem in the model.

Table6. correlation between the Family Ownership and Risk Management with control variables

Depended Variable: Risk Management $\quad Y=-0.048 F O W N$-0.040LEV+0.030FSZE

Variables

The Slope of Line(Fixed Amount)

Family Ownership

LEV

FSZE

$\left(R^{2}\right)$ Coefficient of Determination

Adjusted Coefficient

Statistic F

F Probability Statistic

Durbin Watson

DW Statistic H

\section{Coefficients Statistic t Probability Statistic t}

$0.302 \quad .618$

.077

$-.048$

$-1.202$

.2300

$-.040$

$-.990$

.062

.030

.745

.056

0.073

0.005

1.153

0.327

1.661

1.336335 
In Table 7, the results of the ANOVA test for the model above shows that in this model, the null hypothesis is proved and therefore, the counter-assumption has been rejected by 90 percent confidence level.

Table7. The Analysis of ANOVA

\begin{tabular}{llcccc}
\hline Model & & $\begin{array}{l}\text { Total } \\
\text { Squares }\end{array}$ & $\begin{array}{l}\text { Degree of } \\
\text { Freedom }\end{array}$ & F value & $\begin{array}{c}\text { F probability } \\
\text { (sig.) }\end{array}$ \\
\hline $\begin{array}{l}\text { Dependent Variable: } \\
\text { Risk Management }\end{array}$ & Regression & 2.766 & 3 & & \\
& Residual & 510.098 & 638 & 1.153 & $\mathbf{0 . 3 2 7}$ \\
& Total & 512.863 & 641 & & \\
\hline
\end{tabular}

\subsection{The Fourth Regression Test:}

According to Table 8 , it can be seen that there is a direct negative correlation between the Ownership Concentration and Risk Management meaning that by increasing in the Ownership Concentration, Risk Management decreases. This correlation according to the regression coefficient and statistic $t=-0.236$, sig $=0.043$ is statistically significant. Also, the regression equation regarding the statistic $F=1.689$ at sig $=0.059$ indicates that the overall equation is significant. However, both statistics Durbin Watson DW and Durbin h with values of 1.650 and 1.3327 confirm the lack of serial autocorrelation problem in the model.

Table8. correlation between the Own Concentration and Risk Management with control variables

Depended Variable: Risk Management $\quad Y=-0.0090 W N C-0.045 L E V+0.029 F S Z$

\begin{tabular}{lccc}
\hline Variables & Coefficients & Statistic t & Probability Statistic t \\
The Slope of Line(Fixed Amount) & 0.340 & 0.658 & $\mathbf{0 . 0 5 1}$ \\
Ownership Concentration & -0.009 & -0.236 & .0430 \\
LEV & -0.045 & -1.120 & $\mathbf{0 . 0 6 3}$ \\
FSZE & .0290 & .7240 & .0690 \\
$\mathbf{R}^{2}$ ) Coefficient of Determination & & 0.057 & \\
Adjusted Coefficient & & 0.003 & \\
Statistic F & & 1.689 & \\
F Probability Statistic & 0.059 & \\
Durbin Watson & 1.650 & \\
DW Statistic H & 1.3327 & \\
\hline
\end{tabular}


In Table 9 , the results of the ANOVA test for the model above shows that in this model also, the null hypothesis is rejected and therefore, the counter-assumption has been proved by 90 percent confidence level, and the regression model is in general correct and significant.

Table9.The Analysis of ANOVA

\begin{tabular}{llcccc}
\hline Model & & $\begin{array}{c}\text { Total } \\
\text { Squares }\end{array}$ & $\begin{array}{c}\text { Degree of } \\
\text { Freedom }\end{array}$ & $\begin{array}{c}\text { F value } \\
\text { Dependent Variable: }\end{array}$ & $\begin{array}{c}\text { F probability } \\
\text { (sig.) }\end{array}$ \\
\hline Risk Management & Residual & 511.207 & 638 & 1.689 & 0.059 \\
& Total & 512.863 & 641 & & \\
\hline
\end{tabular}

\section{Conclusions}

Our results assocated with recent researches like Perasetyo[2011]and Lio and Zhu[2009]; wich indicate the significant impact of Mecanisems of Corporate Governance such as the Ownership Structure on Company's Systematic Risk. Results indicate that there is a negative relationship between Institutional Ownership and Risk Management; It means with increase in Institutional , Risk Management will decreased. This is because of that genaraly thought that the peresence of Institutional Ownership, investors may lead to changes in behavior and business practices would regulatory activities of these investors do stems. Computational times compared with definition of Institutional Ownership of shares held by Institutional investors, increase the quality of the company's Ownership Structure. On the other hand, due to the direct effect of Ownership Structure on Risk Management, we can give a clear perspective of the role of Institutional Ownership and increasing factor in the ascending trend of Risk Management in a company,s financial reports control. Based on the other obtained results it can be seen that there is a positive relationship between Management Ownership and Risk Management. The reason for this is that the directors of a company are its ownera. In genera, there is a converyence of interests between managers and owners; and it make managing incentive to be strict as owners in their regulations. So the percentage of ownership of the companys directors can be effective on Risk Management. Also, according to the results, there is a negative relationship between Family Ownership and Risk Management; And one important result was that the persentages of Family Ownership in our sample was verey low; and it also effected on our third hypothes. Also the results shown that there is a negative relationship between Ownership Concentration and Risk Management; Thus we should decrease the Ownership Concentration to managing Systematic Risk truly. 


\section{References}

- Aghai, M; Chalaki, M. [2010]. "The analysis of the correlation between corporate governance characteristics and Risk Management in the companies listed in Tehran Stock Exchange." Accounting Researches, number 4.

- El Ghoul, s; Guedhami,O; Lennox, c. and J. A. Pittman[2007]; "Ownership Structure, Agency Problems, And Auditor Choice: Evidence from Western European Firms." Working Paper. Hong Kong University of Sciences and Technology, Available at: http//:libra.acadiau.ca/library/ASAC/v28/26/2638.pdf.

- Guangming, G.; Menghua, Z.; and G. Xun. [2011]. "Corporate Governance and Cost of Equity Capital." International Conference on Business Management and Electronic Informatio,. India. 13-15 May. Pp. 221-225.

- Ibrahimi, M; Ghanbari, A.[2006]. "Risk Management of Price Fluctuations of Oil in Iran," Economical Letter, volume 2, number 2, pp. 139-162.

- Kumara, Udaya; Guo, Zhaoyang.[2012]"Corporate Governance and Firm Performance of Listed Firms in Sri Lanka", Procedia- Social and Behavioral Sciences, Vol.40, pp.664-667.

- Mahavarpoor,R.[2007]." Study the effect of Ownership Concentration on Performance of firm in TSE", Thesis for receiving «M.A» degree; Alzahra University.

- Mcknight,P.J; Weir,Ch.[2009]. "Agancy Costs,Corporate governance mechanisms and ownership structure in larg UK publicly quoted companies: A panel data analysis", The quarterly Review of Economic and Finance, 49(2): 139-158.

- Mohammadi, A; Lotfi,Sh.[2013], "The Analysis of the Relationship between Board of Director Composition and Risk Management in the Firms Listed in Tehran Stock Exchange"Interdisciplinary Journal of Contemporary Research In Business, ISSN 20737122, IJCRB December Edition 2013-IJCRB Vol .5, No. 8.pp.336-348.

- Prasetyo, A. H. [2011]. "Corporate Governance and Systematic Risk: Evidence from Indonesia Listed Company." International Conference on Economics and Finance Research, Singapore. 26-28 February. pp. 443-449.

- Setayesh, M.H; Dehdari, E; and N. R Namazi. [2011]. "The analysis of corporate governance mechanisms upon efficiency of intellectual capital of components of the companies listed in Tehran Stock Exchange." The Scientific Quarterly of financial Accounting Research. Third year. Number 10, pp. 62-86.

- Vadiee,M.H; \& Gholampoor,H.[2011]." Corporate Governance, Ownership Structure and Firm Performance of TSE" , Collection of Papers in ninth Accounting Conference in Iran, Zahedan, SistanoBalochestan University. 